\title{
Vitamin D and Calcium on Rheumatoid Arthritis in Egyptian Patients
}

\author{
Samar El-Sayed Mahmoud ${ }^{(1)}$, A.T.Keshta ${ }^{(1)}$, Abeer M. El-Shafey ${ }^{(2)}$ \\ ${ }^{(1)}$ Biochemistry Division, Chemistry department, Faculty of Science, Zagazig University. \\ ${ }^{\text {(2) }}$ Rheumatology and Rehabilitation Department, Faculty of Medicine, Zagazig University.
}

\begin{tabular}{ll}
\hline A R T I L E I N F O & A B S R A C T \\
\cline { 2 - 3 } Received : 28/5/2021 & Background: Rheumatoid arthritis (RA) was \\
Available online : 1/9/2021 & characterized by various systemic inflammation of joints \\
& causing damage of bone and cartilage. Aim: The current \\
& study aimed to invistigae serum level of vitamin D and \\
Keywords: & calcium in RA patients compared to healthy control. \\
Rheumatoid arthritis & Materials \&Methods: This study included 90 individuals \\
Calcium & divided into two groups: Healthy volunteers group (15) \\
& and RA group (75) from Rheumatology and \\
& Rehabilitation Department, Faculty of Medicine, Zagazig \\
& university hospitals. Vitamin D and calcium levels in sera \\
& were measured as patients consumed calcium tablets. \\
& Erythrocyte sedimentation rate (ESR), C - reactive protein \\
& (CRP), Rheumatoid Factor (RF), Hemoglobin percentage \\
& (HB \%) and platelet count were collected from data sheet \\
& of patient. Results: There were no significant differences \\
between Vitamin D, calcium (slightly increased in \\
patients) and hemoglobin in both groups. While there \\
were a significant difference in ESR, CRP, RF, and \\
platelet count between RA and healthy control as \\
(p=<0.0001), (p=0.010), (p=0.015) and (p=0.03) \\
respectively. Conclusion: Vitamin D and calcium \\
showed non-significant difference between patients and \\
control.
\end{tabular}

\section{Introduction:}

Rheumatoid arthritis (RA) is defined as a progressive autoimmune disease affecting the bones and cartilage, which occurs in females more than males (1). Early prognosis stays challenging as it depend on the clinical information obtained from the patient's history and physical examination supported by blood tests, and imaging analysis.

The motive for a delayed prognosis vary markedly between nations with differing healthcare systems ${ }^{(2)}$. RA makes synovium inflammation with continuous bone erosion leading to joint loss ${ }^{(3)}$. Vitamin D is fat soluble vitamin derived from cholesterol. It is formed in skin due 
to sun light exposure ${ }^{(4)}$. Calcium has a various biological functions such as regulation of muscle contraction, nerve impulse, and blood coagulation. Calcium and Vitamin D have a crucial role in the promotion of bone health ${ }^{(5)}$. Vitamin D has role in the immunological milieu in the pathophysiology of RA ${ }^{(6)}$. It is also important to growth and remodeling of bone by osteoblasts and osteoclasts ${ }^{(7)}$.

The purpose of the current study is evaluation of serum vitamin $\mathrm{D}$ and calcium levels in RA patients.

\section{Subjects, Materials and Methods:}

Subjects: This study included 90 adult individuals, whose age ranged from (4070 years). These samples were divided into two groups: Group (I): Healthy control group; included 15 (11 females and 4 males) with no evidence of any rheumatologic disorder or chronic medical illness. Group (II): Rheumatoid arthritis (RA) patients included 75 (67 females and 8 males) consumed calcium tablets were selected from Rheumatology and Rehabilitation Department, Faculty of Medicine, Zagazig University Hospitals.

Sampling: $3 \mathrm{ml}$ of blood were collected from each participant in gel-coated tube and serum was extracted by spinning tubes at $5000 \mathrm{rpm}$ for 15 minutes for measurement serum Vitamin D and Calcium levels. Data of patients were collected from data sheet included inflammatory marker ESR, CRP and RF and hematological parameters (HB\% and Platelets count).

Materials: Vitamin D Kit purched from bioactive diagnostic GmbH. Louisentr.137, 61348 Bad Homburg, Germany. Total calcium kit supplied by spinreact.

Methods: Vitamin D levels were measured by Sandwich Enzyme linked Immunosorbant Assay "ELISA" according to method described by Holick ${ }^{(8)}$.Total calcium levels were measured colorimetric according to Farell and Kalpan ${ }^{(9)}$ method.

Statistical Analysis: Data was statistically analyzed with SPSS ${ }^{(10)}$.

\section{Results}

Table (1) summarized vitamin D levels and total calcium levels. The mean levels of vitamin $\mathrm{D}$ were non-significantly decreased between patients "RA group" and healthy control group $(28.4 \pm 13.6$ $\mathrm{ng} / \mathrm{dl})$ and $(24.2 \pm 7.1 \mathrm{ng} / \mathrm{dl})$; respectively $(\mathrm{p}=0.242)$.Figure1

Also, total calcium levels in patients were slightly increased from $(8.1 \pm 0.7$ $\mathrm{mg} / \mathrm{dl}$ ) in healthy control group to $(8.5 \pm 1.3 \mathrm{mg} / \mathrm{dl})$ in RA group, $(\mathrm{p}=0.211)$.

\section{Figure2}

Table (2) summarized ESR, CRP, RF, $\mathrm{Hb} \%$, and platelet count. ESR, CRP and RF levels were significantly increased in patients $(33.9 \pm 21.4 \mathrm{~mm} / \mathrm{h}),(24.1 \pm 29.8$ $\mathrm{mg} / \mathrm{dl}),(64.6 \pm 84.8 \mathrm{IU} / \mathrm{ml})$ compared to healthy control $(3.1 \pm 1.1 \mathrm{~mm} / \mathrm{h}),(3.6 \pm 1.3$ $\mathrm{mg} / \mathrm{dl}),(10.3 \pm 2.2 \mathrm{IU} / \mathrm{ml})$; respectively $(\mathrm{p}<0.0001), \quad(\mathrm{p}=0.010)$ and $(\mathrm{p}=0.015)$; respectively. Figure3,4,5

On the other hand, hematological parameters (HB\% and platelets count) showed significant difference between two groups. For RA group (12.2 \pm 1.1 $\mathrm{g} / \mathrm{dl}),(269.4 \pm 80.3 \mathrm{k} / \mathrm{Ul})$ and for control group $(12.6 \pm 0.5 \mathrm{~g} / \mathrm{dl}),(221.7 \pm 54.4 \mathrm{k} / \mathrm{UI})$ as $(\mathrm{p}=0.174)$ and $(\mathrm{p}=0.03)$; respectively.

\section{Figure6,7}

Table (3) illustrated the correlations between all biochemical parameters. None of them was correlated with any one of biochemical parameters.

\section{Discussion}

RA is characterized by autoantibody production against citrullinated peptides in self-protein citrullination. Meanwhile, citrullination process is catalyzed via the calcium-dependent enzyme peptidylarginine- deiminase (PAD), that change the positive charge of arginine into polar ${ }^{(11)}$. Vitamin D has a vital function in the regulation and differentiation of 
immune cells. Studies suggested that vitamin $\mathrm{D}$ deficiency is associated with autoimmune disorder such as rheumatoid arthritis, Type 1 diabetes mellitus, multiple sclerosis and systemic lupus erythematous ${ }^{(12)}$. Vitamin D is also critical for bone health, and it helps the body to absorb calcium. Vitamin D promotes absorption of calcium in the intistien and maintains enough serum calcium concentrations to allow ordinary mineralization of bone and to prevent hypocalcaemia ${ }^{(7)}$. Vitamin D is a homeostatic regulation as it is a key factor of the regulation of circulating calcium tries through increasing the absorption of calcium in the upper small bowel and through stimulating osteoclastic bone resorption ${ }^{(4)}$.

The current study demonstrated that no significant difference in sera vitamin D levels in RA patients and control subjects. This may be due most patients were farmer, so duration of exposure to sunrise is too long so they obtain enough amount of vitamin D from sun. Our data were in a line with Mukhtar et al. ${ }^{(\mathbf{1 3})}$ who conducted in Pakistan population, In contrast to current findings, researches from more than one geographical regions and nations and their meta evaluation recommended significant inverse correlation between vitamin $\mathrm{D}$ and disease onset in RA patients ${ }^{(14,15)}$.

Calcium levels were slightly increased in patients than in control because patients consumes calcium tablets as part of treatment. This result agrees with Saptarini et al., (16). In contrast another study by Scott et al., (17) demonstrated that serum calcium levels in RA patients are lower than in healthy subjects.

On the other hands, the routine clinical parameters as ESR, CRP, $\mathrm{RF}, \mathrm{Hb} \%$, and Plts count showed significant increase in RA patients than control. ESR is an indirect marker of inflammation ${ }^{(18)}$.ESR display the past few weeks of disorder activity in RA. Also, CRP is one of the best indicators of inflammation. It is synthesized in hepatocytes and its level eleuvate in cases of infection, inflammation, malignancy and tissue damage. CRP is a member of the pentraxin protein family (19). CRP synthesis is regulated as part of the human acute-phase response, which is a dramatic alteration in response to infection, inflammation or tissue injury in the response of hepatic proteins synthesized ${ }^{(20)}$. CRP certainly acts as an opsonin coating microbial particles and demise cells to promote bacterial killing and the induction of phagocytosis. As $\mathrm{CRP}$ interacts with $\mathrm{Clq}$, resulting in subsequent activation of the early levels of the classical complement cascade ${ }^{(21)}$. The outcomes of opsonization by CRP are, however, complicated with CRP activating oversease range of immunological pathways. It has been reported that CRP can act as a ligand for both low-affinity and high-affinity Fc $\gamma$ receptors on phagocytes ${ }^{(22)}$. Attachment of CRP to Fc $\gamma$ RI and Fc $\gamma$ RIIA typically promotes the release of pro-inflammatory cytokines, whereas binding of CRP to Fc $\gamma$ RIIB leads to inhibition of cell activation; CRP can therefore have each pro-inflammatory and anti-inflammatory effects.

RF auto antibodies are directed against the Fc portion of the IgG. This autoantibody is an early biomarker of RA ${ }^{(\mathbf{2 3})}$. There are different clinical parameters were examined in the evaluation of RA including; Hematological parameters as Hemoglobin $(\mathrm{Hb} \%)$, and acute phase proteins (thrombocytic count, CRP, ESR), rheumatoid factor (RF). Although in the study, CRP is concept to be the better test in relation to measurement of acute phase it has been stated that ESR may be better than CRP in general measurement even in cases when inflammation is very low because it is sensitive to immunoglobulins and RF (24). The highly expression of these biomarkers are related to disease activity. 
Our study showed that ESR, CRP has a potent relationship with RA. Olcum et al observed that ESR showed better correlation in study group in contrast there was no relation for CRP ${ }^{(25)}$, other study observed positive but weak correlation for ESR and CRP in RA patients ${ }^{(26)}$, CRP has a moderately strong relationship with disease activity ${ }^{(27)}$, Koo et $a l^{(\mathbf{2 8})}$ showed that ESR is a non-specific inflammatory marker. Rheumatoid factor is one of several auto antibodies that characterize RA ${ }^{(29)}$. Our studies demonstrated that RF is associated with RA susceptibility, other studies agrees with own study ${ }^{(30,31)}$. Platelets count showed significant increase in RA other study in a line and confirmed that thrombocytosis is often seen in patients with active RA ${ }^{(32)}$.

Conclusion: Vitamin D and calcium showed non-significant difference between patients and control.

\section{References:}

1- Silman AJ and Pearson JE. Epidemiology and genetics of rheumatoid arthritis. Arthritis Res., 2002; 4(Suppl. 3):S265S272.

2- Raza K, Stack R, Kumar K, Filer A and Detert J. Delays in assessment of patients with rheumatoid arthritis: variations across Europe. Ann. Rheum. Dis. 2011; 70(10):1822-1825.

3- Tobon GJ, Youinou P, Saraux A. The environment, geoepidemiology and autoimmune disease: rheumatoid arthritis. Journal of Autoimmunity 2010; 9(5):A288-A292.

4- Reid IR and Bolland MJ. Calcium and/or Vitamin D Supplementation for the Prevention of Fragility Fractures: Who Needs It? Nutrients, 2020; 12(4): 1011.
5- Torres S, Kroneck $M$ and Peter MH. "Introduction: From Rocks to Living Cells" pp 1-32 in "Metals, Microbes and Minerals: The Biogeochemical Side of Life". 2021; pp xiv + 341.

6- Bellan M, Sainaghi PP and Pirisi M. Role of Vitamin D in Rheumatoid Arthritis. Adv Exp Med Biol.2017; 996: 155-168.

7- Holick MF. Resurrection of Vitamin D deficiency and rickets. J Clin Invest; 2006; 116(8):2062-72.

8- Holick MF. Vitamin D Status: Measurment, Interpretation and clinical Application. Ann Epidemoil.2009; 19 (2):73-78.

9- Farell EC. and Kaplan A. Calcium Clin Chem the C.V. Mosby Co. St Louis. Toronto. Princeton.1984; 1051-1255 and 418.

10-Levesque R. SPSS Programming and Data Management: A Guide for SPSS and SAS Users, Fourth Edition ، SPSS Inc., Chicago, IL.2007; 60606-6412.

11- Guo Q, Wang Y, Xu D, Nossent J, Pavlos NJ and Xu J. Rheumatoid arthritis: pathological mechanisms and modern pharmacologic therapies. Bone Research 2018; 6(1) 1-14.

12-Arnson $\mathrm{Y}$, Amital $\mathrm{H}$ and Shoenfield Y. Vitamin D and autoimmunity: new etiological and therapeutic considerations. Ann Rheum Dis; 2007; 66(9):1137-1142.

13- Mukhtar M, Sheikh N, Suqaina SK, Batool A, Fatim N, Mehmood $\mathrm{R}$ and Nazir S. Vitamin D Receptor Gene Polymorphism: An Important Predictor of Arthritis 
Development: Volume, Article ID2019; 8326246, 8 pages.

14- Meena N, Chawla SPS, Garg R, Batta A and Kaur S. Assessment of Vitamin D in Rheumatoid Arthritis and Its Correlation with Disease Activity: Journal of Natural Science, Biology and Medicine IP: 2018; 9(1): 54-58.

15- Atoum $\mathrm{M}$ and Alzoughool $\mathrm{F}$. Vitamin D deficiency and rs731236 (Taq1) vitamin D receptor gene polymorphism as possible risk factors for rheumatoid arthritis and osteoarthritis: Acta Medica Mediterranea, 2018; 34(1): 209.

16- Saptarini NM, Wibowo MS and Gusdinar T. Correlation Study Of Serum Calcium Levels And Serum Cartilage Oligomeric Matrix Protein Levels In Rheumatoid Arthritis Patients In Bandung, Indonesia. Asian $J$ Pharm Clin Res, 2017; 10(11): 401-403.

17-SCOTT DL, FARR M, HAWKINS CF, WILKINSON $\mathrm{R}$ and BOLD A.M. (1981): Serum calcium levels in rheumatoid arthritis; 1981; 40(6): 580-3.

18- Olcum GG, Yagan FCC, Cekin $\mathrm{R}$, Tasan DA, Erdoga $\mathrm{M}$ and Aliustaoglu M. Relationship between Disease Activation, Serum Erythrocyte Sediment Level and C-reactive Protein Level in Rheumatoid Arthritis Patients Receiving Anti-Tumor Necrosis Factor Alpha Treatment: 2017; 1(2):69-75.

19- Pepys MB and Hirschfield GM. C-reactive protein: a critical update. J. Clin. Invest. 2003; 111(12): 1805-1812.

20-Rhodes B, Fürnrohr BG and Vyse TJ. C-reactive protein in rheumatology: biology and genetics. Nature Reviews
Rheumatology, 2011; 7(5): 282289.

21- Mold C, Gewurz H and Du Clos TW. Regulation of complement activation by C-reactive protein. Immunopharmacology. 1999; 42(1-3): 23-30.

22- Peisajovich A, Marnell L, Mold $\mathrm{C}$ and Du Clos TW. C-reactive protein at the interface between innate immunity and inflammation. Expert Rev. Clin. Immunol. 2008; 4(3):379-390.

23- Jansen DTS, Emery P, Smolen JS, Westhovens R, Le Bars M, Connolly SE, Ye J, Toes REM and Huizinga T.W.J. Conversion to seronegative status after abatacept treatment in patients with early and poor prognostic rheumatoid arthritis is associated with better radiographic outcomes and sustained remission: post hoc analysis of the AGREE study. RMD Open, 2018; 4(1): e000564.

24-Wolfe F. Comparative usefulness of C-reactive protein and erythrocyte sedimentation rate in patients with rheumatoid arthritis. J Rheumatol 1997; 24(8):1477-85.

25- Olcum GG, Yagan FCC, Cekin $\mathrm{R}$, Tasan DA, Erdoga $\mathrm{M}$ and Aliustaoglu M.(2017) :Relationship between Disease Activation, Serum Erythrocyte Sediment Level and C-reactive Protein Level in Rheumatoid Arthritis Patients Receiving Anti-Tumor Necrosis Factor Alpha.2017;1(2):69-75.

26-SUNAR I and ATAMAN S. Serum C-Reactive Protein/Albumin Ratio in Rheumatoid Arthritis and its Relationship with Disease Activity, Physical Function, and Quality of Life. Arch Rheumatol 2020; 35(2):247-253. 
27-Orr CK, Najm A, Young F, Garry TM, Biniecka M, Fearon $\mathrm{U}$ and Veale DJ. The Utility and Limitations of CRP 'ESR and DAS28-CRP in Appraising Disease Activity in RheumatoidArthritis: 2018 doi: 10.3389/fmed.00185.

28- Koo BS, Hong S, Kim YJ, Kim YG, Lee CK and Yoo B. Clinical Characteristics of Patients with Rheumatoid Arthritis Who have Sustained High Erythrocyte Sedimentation Rates after Clinical Remission: 2014;2 1(1): 20-24.

29- Klaasen R, Cantaert T, Wijbrandts CA, Teistsma C, Gerlag DM, Out TA, Nooijer MJ, Baeten D and Tak PP. The value of rheumatoid factor and anti-citrullinated protein antibodies as predictors of response to infliximab in rheumatoid arthritis :an exploratory study Rheumatology (Oxford), 2011; 50(8): 1487-93.

30- Aletaha D, Alasti F and Smolen JS. Rheumatoid factor, not antibodies against citrullinated proteins, is associated with baseline disease activity in rheumatoid arthritis clinical trials: 2015; 17(1): 1-10.

31- Agrawal S, Misra $\mathrm{R}$ and Aggarwal A. Autoantibodies in rheumatoid arthritis: association with severity of disease in established RA. Clin Rheumatol; 2007; 26(2):201-204.

32-HUTCHINSON RM, DAVIS P and JAYSON MIV. (1976): Thrombocytosis in rheumatoid arthritis: Ann. rheum. Dis., 1976; 35(2): 138-142. 
Table 1: Vitamin D and Calcium levels in two studied groups:

\begin{tabular}{|l|c|c|c|}
\hline \multicolumn{1}{|c|}{ Variables } & Control $(\mathbf{n}=\mathbf{1 5})$ & Patients $(\mathbf{n}=\mathbf{7 5})$ & P value \\
\hline Vitamin D & $24.2 \pm 7.1$ & $28.4 \pm 13.6$ & 0.242 \\
\hline Calcium & $8.1 \pm 0.7$ & $8.5 \pm 1.3$ & 0.211 \\
\hline
\end{tabular}

Vitamin D

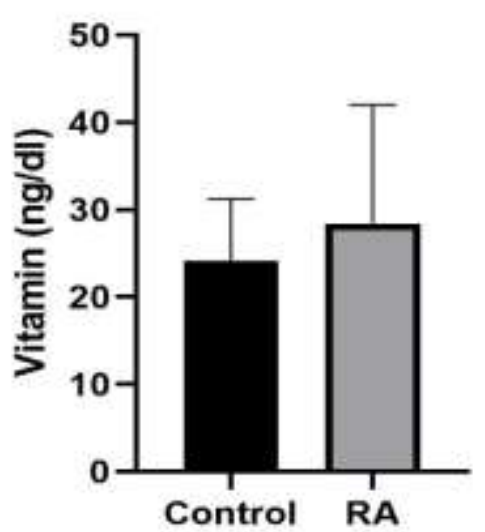

Figure 1:Mean level of Vitamin D in both group.

\section{Calcium}

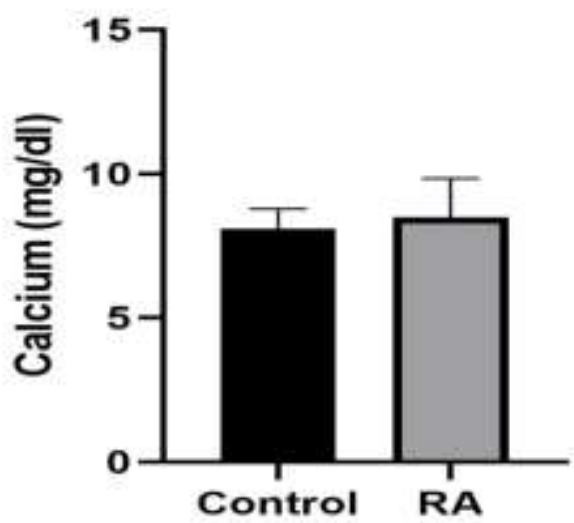

Table 2: Comparison of clinical parameters between patients and control:

\begin{tabular}{|l|c|c|c|}
\hline \multicolumn{1}{|c|}{ Variables } & Control $(\mathbf{n}=\mathbf{1 5})$ & Patients $(\mathbf{n}=\mathbf{7 5})$ & P value \\
\hline ESR & $3.1 \pm 1.1$ & $33.9 \pm 21.4$ & $<0.0001$ \\
\hline CRP & $3.6 \pm 1.3$ & $24.1 \pm 29.8$ & 0.010 \\
\hline RF & $10.3 \pm 2.2$ & $64.6 \pm 84.8$ & 0.015 \\
\hline Hb\% & $12.6 \pm 0.5$ & $12.2 \pm 1.1$ & 0.174 \\
\hline Plts & $221.7 \pm 54.4$ & $269.4 \pm 80.3$ & 0.03 \\
\hline
\end{tabular}

Figure 2:Mean level of calcium in both group.

ESR

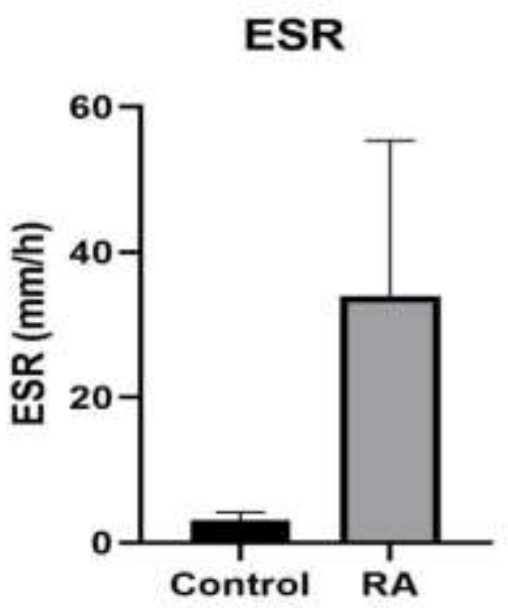

Figure 3:Mean level of ESR in both group.

\section{CRP}

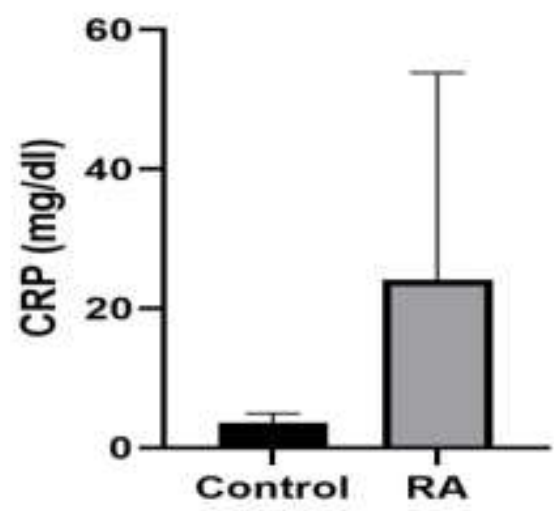

Figure 4:Mean level of CRP in both group. 


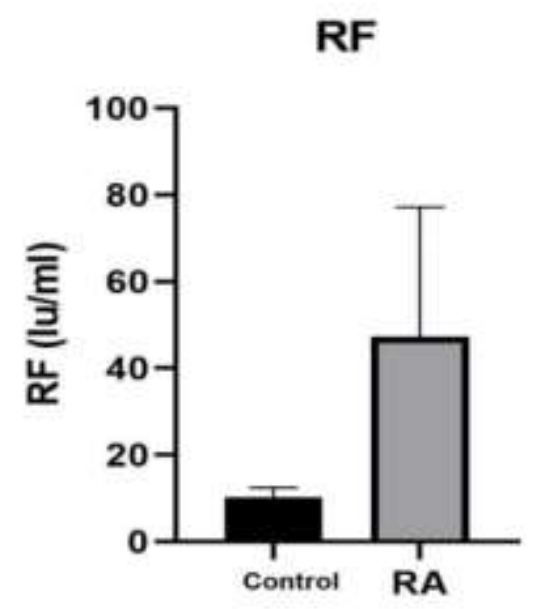

Figure 5:Mean level of RF in both group.
Hemoglobin

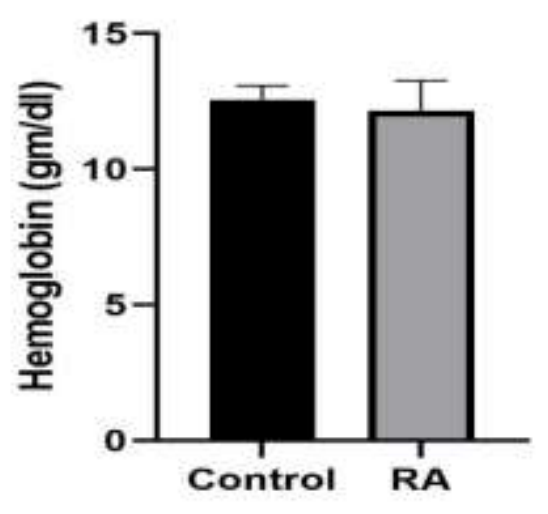

Figure 6 :Mean level of $\mathrm{HB} \%$ in both group.

\section{Platelet count}

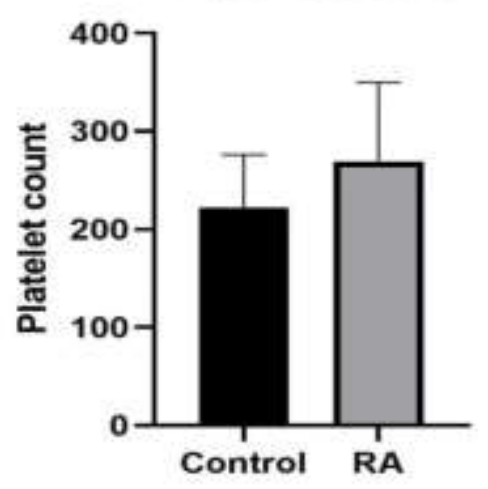

Figure 7:Mean level of platlets in both group. 
Table 3: The correlation between all biochemical parameters:

\begin{tabular}{|c|c|c|c|c|c|c|c|c|}
\hline Parameters & & НВ \% & PLT & ESR & RF & CRP & Calcium & $\begin{array}{c}\text { Vitamin } \\
\text { D }\end{array}$ \\
\hline НВ\% & $\mathrm{r} / \mathrm{p}$ & --- & & & & & & \\
\hline PLT & $\mathrm{r} / \mathrm{p}$ & $\begin{array}{l}0.000 \\
0.999\end{array}$ & --- & & & & & \\
\hline ESR & $\mathrm{r} / \mathrm{p}$ & $\begin{array}{c}- \\
0.306 * \\
0.003\end{array}$ & $\begin{array}{l}0.131 \\
0.217\end{array}$ & --- & & & & \\
\hline RF & $\mathrm{r} / \mathrm{p}$ & $\begin{array}{l}0.120 \\
0.260\end{array}$ & $\begin{array}{c}0.107 * \\
0.314\end{array}$ & $\begin{array}{c}0.211 * \\
0.046\end{array}$ & --- & & & \\
\hline CRP & $\mathrm{r} / \mathrm{p}$ & $\begin{array}{l}0.112 \\
0.292\end{array}$ & $\begin{array}{l}0.203 \\
0.055\end{array}$ & $\begin{array}{c}0.302 * \\
0.004\end{array}$ & $\begin{array}{c}0.331^{*} \\
0.001\end{array}$ & --- & & \\
\hline Calcium & $\mathbf{r} / \mathbf{p}$ & $\begin{array}{c}-0.038 \\
0.726\end{array}$ & $\begin{array}{l}0.038 \\
0.725\end{array}$ & $\begin{array}{l}0.092 \\
0.390\end{array}$ & $\begin{array}{l}0.175 \\
0.099\end{array}$ & $\begin{array}{c}- \\
0.014 \\
0.895\end{array}$ & --- & \\
\hline Vitamin D & $\mathrm{r} / \mathrm{p}$ & $\begin{array}{c}-0.111 \\
0.299 \\
\end{array}$ & $\begin{array}{l}0.034 \\
0.750 \\
\end{array}$ & $\begin{array}{l}0.127 \\
0.232 \\
\end{array}$ & $\begin{array}{l}0.093 \\
0.386 \\
\end{array}$ & $\begin{array}{l}0.053 \\
0.622 \\
\end{array}$ & $\begin{array}{c}-0.217^{*} \\
0.040\end{array}$ & - \\
\hline
\end{tabular}

*Correlation is significant at the 0.05 level (2-tailed).

** Correlation is significant at the 0.01 level (2-tailed). 